\title{
The Use of the Mandibular Ramus for Alveolar Reconstruction in Oral Implantology
}

\author{
Uso de Rama Mandibular para Reconstrucción Alveolar en Implantología Oral
}

\author{
Marcelo Parra ${ }^{1,2}$; Ziyad S. Haidar ${ }^{3,4}$; José Valdivia Osorio5; Nadia Araneda ${ }^{6}$ \& Sergio Olate²,5
}

PARRA, M.; HAIDAR, Z. S.; VALDIVIA, O. J.; ARANEDA, N. \& OLATE, S. The use of the mandibular ramus for alveolar reconstruction in oral implantology. Int. J. Odontostomat., 11(2):236-242, 2017.

\begin{abstract}
Bone grafts are widely used in alveolar ridge augmentations to allow correct implant installations. Intraoral donor sites, such as the maxillary tuberosity, symphysis and mandibular ramus have presented good characteristics and outcomes; however, the mandibular ramus has comparative advantages that promote its increased use. The aim of this work is to describe the current results of the mandibular ramus as a donor site for obtaining bone grafts to be used in alveolar bone augmentations in oral implantology and to determine the survival rate of the implants installed in the grafted sites. A systematic search of the scientific literature between December 2000 and March 2017 was carried out on the MEDLINE, EMBASE, LILACS and SciELO databases, analyzing each article according to the method of diagnosis and planning, bone resorption at the receptor site, presence of postoperative complications and implant survival rate. Eleven works were included in this study with an average of 43 patients; the follow-up times varied between 6 and 120 months, considering in addition an average success rate of $98.7 \%$ in the implants installed in sites reconstructed with mandibular ramus bone; low morbidity in the site mainly linked to temporary neurosensory alterations was identified. It may be concluded that the need for a second surgical site to obtain graft material and the longer time the treatment requires until implant rehabilitation continue to be disadvantages; nevertheless, the mandibular ramus donor site presents low morbidity, high versatility in its use and predictable results for the dental implant installation.
\end{abstract}

KEY WORDS: mandibular ramus, bone graft, dental implants.

\section{IINTRODUCTION}

Bone grafts are widely used to increase atrophic alveolar ridges so dental implants can be correctly installed, and they have evolved considerably in the last decade. Nowadays there is a wide variety of materials (Deluiz et al., 2017); however, the "gold standard" in bone grafts continues to be autogenous bone due to its osteogenic, osteinductive and osteoconductive properties (Diez et al., 2014). Previous studies have described bone remodeling of the graft, revascularization and new bone formation at the graft site, which provide suitable conditions to support the occlusal forces of an implant-supported prosthesis.
The use of autogenous donor sites continues to be a technique used, and although the iliac crest and calvaria have shown good results, obtaining bone from these areas has major clinical time and cost implications, in addition to being sites of greater morbidity (Restoy-Lozano et al., 2015).

Intraoral donor sites, such as maxillary tuberosity, symphysis and mandibular ramus, however, have recognized advantages in terms of stability, functionality and prognosis in dentoalveolar reconstructions (Reininger et al., 2016). In this sense,

\footnotetext{
${ }^{1}$ Programa de Doctorado en Ciencias Morfológicas, Universidad de La Frontera, Temuco, Chile.

${ }^{2}$ División de Cirugía Oral y Maxilofacial \& CEMYQ, Universidad de La Frontera, Temuco, Chile.

${ }^{3}$ BioMAT'X-CIB, Facultad de Odontología, Universidad de Los Andes, Santiago, Chile.

${ }^{4}$ Programa de Doctorado en BioMedicina, Facultad de Medicina, Universidad de Los Andes, Santiago, Chile.

${ }^{5}$ Programa de Especialización en Implantología Buco Maxilofacial, Universidad Autónoma de Chile, Chile.

${ }^{6}$ Programa de Magister en Odontología, Universidad de La Frontera, Temuco, Chile.
} 
mandibular donor sites mostly present cortical bone and limited loss of volume (Lee \& Kim, 2015), observing new bone formation at the donor site 6 months after bone removal (Lee \& Kim); on the other hand, this donor site, when found in the same operative field, also allows for speed and rationalization of the use of the anesthesia.

The most frequently used mandibular sites are the chin and mandibular ramus; the ramus has certain advantages over the symphysis, such as minimal concern on the part of the patient for alteration of their facial contour, lower incidence of suture dehiscence and fewer postoperative complications (Reininger).

The aim of this work is to conduct a contemporary analysis of autogenous bone grafts extracted from the mandibular ramus for use in alveolar bone augmentations in oral implantology and also to determine the survival rate of the implants installed in these grafted sites.

\section{MATERIAL AND METHODS}

Search strategy. A systematic search was made of the scientific literature between December 2000 and March 2017 in the MEDLINE, EMBASE, LILACS and SciELO databases. MeSH terms and free terms were used and then the Boolean terms "OR" and AND" were applied. The search algorithm used for the search in MEDLINE was: ((((“Bone Transplantation"[Mesh] OR autologous bone graft)) AND ((("Mandible"[Mesh]) OR mandibular ramus) OR mandibular donor site)) AND "Dental Implants"[Mesh]. The search was complemented by a manual review of the references from the articles included.

Eligibility criteria. The inclusion criteria were as follows: 1) articles published in Spanish, English and Portuguese, 2) studies conducted on humans, 3) articles in which autogenous bone was extracted from the mandibular ramus, and 4) articles in which bone reconstructions were done for dental implant installation. Animal studies, secondary studies and those where bone reconstructions were done for purposes other than the dental implant installation were excluded.

Study variables and data analysis. The variables analyzed in this review were: method of diagnosis and surgical planning, bone resorption in the receptor site, postoperative complications and implant survival rate. The data were extracted according to the requirements, with data being presented as tables for their study; no data meta-analysis was done.

\section{RESULTS}

Study selection. Once the combined search was complete, there were 546 titles. After eliminating duplicates and reviewing abstracts, 53 articles were obtained for a full text analysis; subsequent to this analysis, the inclusion and exclusion criteria were applied and a total of 11 articles was selected and used in this review (Table I).

With respect to excluded articles, these were mainly studies conducted on animals, secondary studies and studies in which bone reconstructions were performed for purposes other than dental implant installation.

Characteristics of the studies . The average number of patients was 43 and varied from 1 to 109 patients. Of the 11 articles analyzed, 9 were prospective and 2 were retrospective. In all the studies, implant installation was delayed; i.e., healing time was expected after graft placement, which was 3 to 5 months in the study by Soehardi et al. (2009), 4 months in the works by Happe (2007), Cordaro et al. (2011) and Streckbein et al. (2014), 4 to 5 months in the studies by Restoy-Lozano et al. (2015) and Sakkas et al. (2016); 5 months in the work by Singh et al. (2013), and 4 to 6 months in the study by Voss et al. (2016). On the other hand, in the works by Prousaeffs et al. (2002) and Greenberg et al. (2012), the expected time was 6 months, whereas in the work by Peñarrocha-Oltra et al. (2014) it was 7 months.

Diagnosis methods and planning. With respect to the evaluation method, 6 studies were conducted using orthopantomography (Happe, Soehardi et al., Cordaro et al., Streckbein et al., Sakkas et al. and Voss et al.), two studies used tomography (Greenberg et al. and Peñarrocha-Oltra et al.), Singh et al. performed their analysis with retroalveolar x-rays, and Restoy-Lozano et al. used panoramic x-rays and computed tomography. Prousaeffs et al. conducted their study using retroalveolar and panoramic x-rays and histological and histomorphometric studies when the implants were installed. 


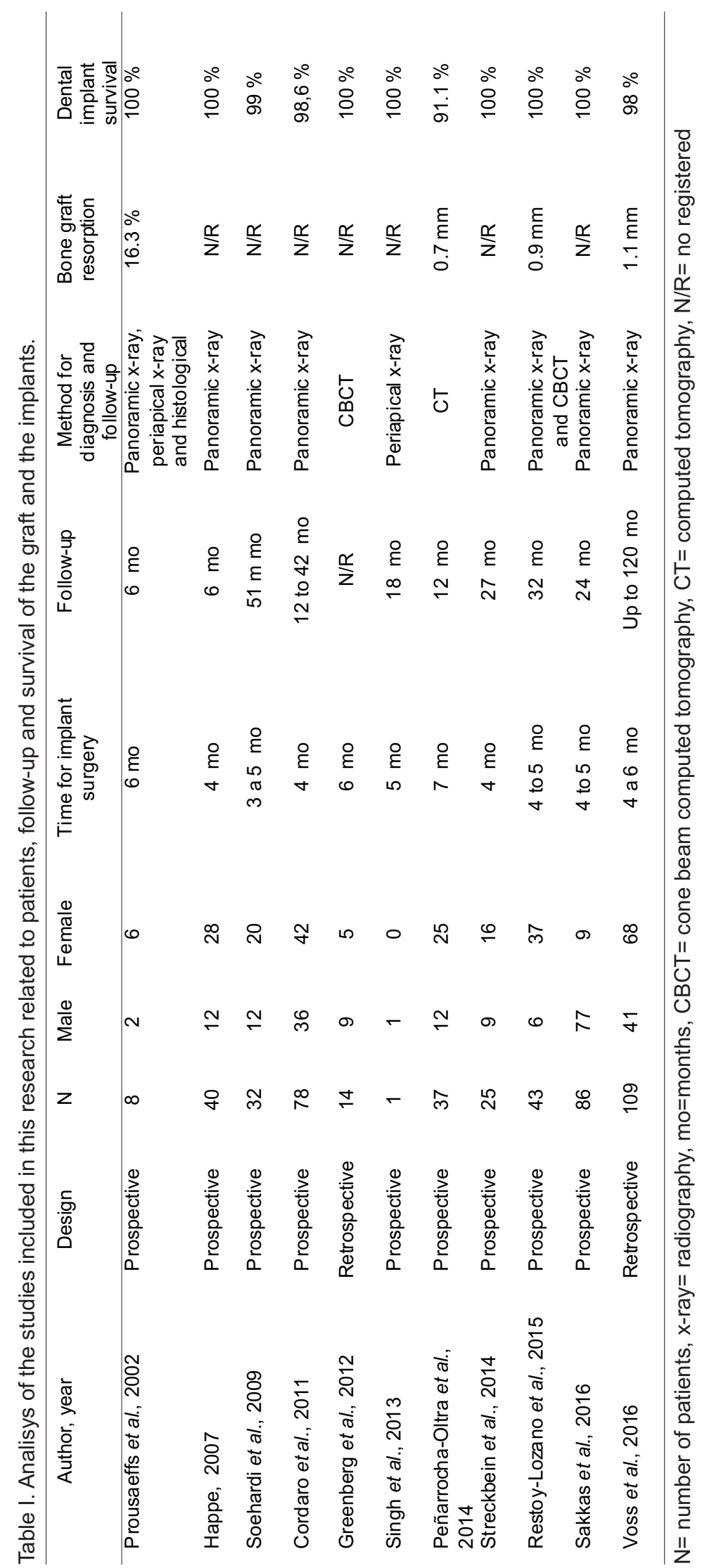

Histological analyses. Prousaeffs et al. conducted histological and histomorphometric analyses on bone samples $2 \mathrm{~mm}$ in diameter obtained from the grafted sites when the dental implants were installed; these samples were fixed in $10 \%$ formalin, dehydrated with alcohol, and embedded in resin ("Technovit 7200 VLC, Kulzer, Wehrheim", Germany), cut in thicknesses from 40 to $50 \mathrm{~mm}$ and then dyed with Stevenel's blue and Van Gieson's stains for light microscopy. The results of the histological analysis showed a solid core, composed mainly of cortical bone, with obvious signs of bone remodeling activity. The histomorphometric analysis revealed that approximately $45 \%$ corresponded to newly formed bone and almost $30 \%$ to fibrous tissue.

Bone resorption at the receptor site. Some of the studies included in this review report lower rates of bone resorption at the receptor site in the first year of follow-up. Peñarrocha-Oltra et al. reported an average of $0.7 \mathrm{~mm}$; Restoy-Lozano et al., $0.9 \mathrm{~mm}$ and Voss et al. $1.075 \mathrm{~mm}$; Happe, Soehardi et al., Cordaro et al., Greenberg et al., Singh et al., Streckbein et al. and Sakkas et al. did not report on bone resorption rates at the receptor site.

Postoperative Complications. An average of postoperative complica-tions at the donor site was estimated to be $6.51 \%$ among the studies. The study by Prousaeffs et al. reported 1 case of slight pain (12.5 $\%)$; Happe reported 1 case of dehiscence, 1 case of infection with suppuration and 1 case of alteration of lower lip sensitivity representing $7.5 \%$ of the total cases; in the study by Soehardi et al., $22 \%$ of the cases presented some type of postoperative complication, being mainly a slight paresthesia in the symphyseal area; Cordaro et al. reported that $6.4 \%$ of their cases presented some type of postoperative complication, mainly alterations in sensitivity; Streckbein et al. indicated the presence of 1 case of dysesthesia; Restoy-Lozano et al., from a total of 43 subjects, reported 3 cases of edema and one case of infection, while 
Sakkas et al. described 3 cases of donor site infection, corresponding to $3.4 \%$ of the subjects. Greenberg et al., Singh et al. and Peñarrocha-Oltra et al. indicated that no postoperative complications were observed. In the study by Voss et al., the presence or absence of postoperative complications at the donor site was not reported. The postoperative complications are detailed in Table II.

Dental implant survival rate. With respect to the survival rate of the implants installed in grafted sites, an average of $98.7 \%$ was estimated among the studies. This was $91.1 \%$ in the study by PeñarrochaOltra et al., $98 \%$ in the work by Voss et al., $98.6 \%$ in the study by Cordaro et al., $99 \%$ in the case of Soehardi et al. and $100 \%$ in the works by Prousaeffs et al., Happe, Greenberg et al., Singh et al., Streckbein et al., Restoy Lozano et al. and Sakkas et al.

\section{DISCUSSION}

Autogenous block grafts, used in alveolar bone reconstructions, have made it possible to achieve high success rates with implants. With respect to where these grafts are obtained, the mandibular ramus has been shown to be a reliable donor site, as it can rationalize the use of time and presents lower morbidity and postoperative complications, being better accepted by patients than other mandibular donor sites, like the symphysis (Reininger et al.).

Analysis of the studies included reveal that most of them conducted their planning using $2 \mathrm{D}$ or $3 \mathrm{D}$ images, but few studies conducted a histological analysis of the newly formed tissue to determine the characteristics of the new bone structure.

Table II: Complications related to the donor site reported in the studies included in this research.

\begin{tabular}{|c|c|c|c|}
\hline Author, year & $\begin{array}{l}\text { Pos-operative } \\
\text { complications in the } \\
\text { donor site }\end{array}$ & $\begin{array}{l}\text { Description of complications in the } \\
\text { don or site }\end{array}$ & $\%$ of complications \\
\hline Prousaeffs et al., 2002 & Yes & Low pain (1 case) & $12.5 \%$ \\
\hline Happe , 2007 & Yes & $\begin{array}{l}\text { Lost of suture (1 case), infection (1 case), } \\
\text { sensitivity dysfunction in the lower lip (1 } \\
\text { case) }\end{array}$ & $7.5 \%$ \\
\hline Soehardi et al., 2009 & Yes & $\begin{array}{l}\text { Mild paraesthesia in the chin (6 cases), } \\
\text { infection ( } 1 \text { case) }\end{array}$ & $22 \%$ \\
\hline Cordaro et al., 2011 & Yes & $\begin{array}{c}\text { Hypoaesthesia ( } 4 \text { cases), paraesthesia (1 } \\
\text { case), mild pain ( } 1 \text { case) }\end{array}$ & $6.4 \%$ \\
\hline Greenberg et al. , 2012 & No & & $0 \%$ \\
\hline Singh et al., 2013 & No & & $0 \%$ \\
\hline Peñarrocha-Oltra et al., 2014 & No & & $0 \%$ \\
\hline Streckbein et al., 2014 & Yes & Dysesthesia ( 1 case) & $4 \%$ \\
\hline Restoy Lozano et al., 2015 & Yes & Infection ( 1 case), edema ( 3 cas es) & $9.3 \%$ \\
\hline Sakkas et al., 2016 & Yes & Infection (3 cases) & $3.4 \%$ \\
\hline Voss et al., 2016 & $N / R$ & $N / R$ & $N / R$ \\
\hline
\end{tabular}

$\mathrm{N} / \mathrm{R}=$ no reported 
In relation to the postoperative complications of the mandibular ramus as a donor site, there were 7 studies that reported complications (Prousaeffs et al.; Happe; Soehardi et al.; Cordaro et al.; Streckbein et al.; Restoy-Lozano et al., Sakkas et al.), presenting an estimated average of postoperative complications of $6.51 \%$, with the most frequently observed being surgical wound infections and slight alterations in sensitivity in the donor area and lower lip of the corresponding hemiarch. The cases of infection, treated with antibiotics, limited the local infectious processes and in the case of the sensory alterations, these disappeared in a period of not more than 1 year. Analyzing the bone harvesting from the mandibular symphysis, the review done by Nkenke \& Neukam (2014) demonstrated $29 \%$ with sensory alterations, with endodontic treatment being needed in some teeth of the anteroinferior sector.

Noia et al. (2011) found almost $30 \%$ neurosensory alterations in bone extractions from the mandibular symphysis, whereas Velázquez et al. (2017) indicated that the limited amount of cortical bone in the mandibular symphysis and the proximity to the apical dental region could be one of the causes of the major neurosensory complications in the zone. Rocha et al. (2010) indicated that the position of the ramus and the possibility of extension when removing the bone through the oblique line could reduce the neurosensory complications, where the use of ultrasonic systems also has a positive impact on reducing surgical site morbidity (Olate et al., 2013).

Other studies have demonstrated sufficient cortical bone from this anatomical zone, close to $3 \mathrm{~mm}$ in the lateral region, to allow efficient installation of an osteosynthesis screw with good stability to ensure integration of the block (De Oliveira et al., 2012). Therefore, selection of the type of osteosynthesis may be a relevant aspect in the block installation technique (Netto et al., 2013b) since the type of screw, its shape, size and the material with which it is made present different mechanisms in the graft integration; in addition, the block graft can be incorporated into the receptor bed either by putting the cancellous bone or the cortical bone directly in contact with the receptor bed, which gives the bone extracted from the mandibular ramus greater versatility, considering the sometimes complex morphologies in the receptor bed (Netto et al., 2013a).

Considering that autogenous bone continues to be the "gold standard" (Kluppel et al., 2013), with contemporary applications in both large maxillofacial reconstructions (Fariña et al., 2016) and in smaller reconstructions (Netto et al., 2016), other alternatives for the autogenous block graft extracted from the mandibular ramus have preferentially used homogenous or heterogeneous bone blocks with controversial results. Deluiz et al. (2016) studied postoperative complications in 58 patients who required implant-assisted rehabilitation and augmented volume with a block allograft. After 4 to 6 months of healing, the corresponding implants were installed: a total of 268 implants. In a 12-month follow-up period, the complications found were: infection (10.3\%), surgical wound dehiscence (8.62 \%), mucosal perforation $(12.07 \%)$, partial graft loss $(6.9 \%)$ and total graft loss $(5.17 \%)$. In addition, 16 (5.97\%) of the 268 implants failed. Although the use of an alloplastic graft for block reconstructions reduces morbidity when a donor site is not needed to obtain the bone graft, the study by Deluiz et al. described other types of postoperative complications associated with alloplastic grafts, such as partial or total graft loss. Chiapasco et al. (2015) reported 19 subjects with atrophic maxillae with human allogenic block grafts, of which 4 completely lost the reconstruction due to exposure of the previous graft to the implant installation, and 9 patients presented exposure and partial graft loss after the installation, concluding that such material is significantly associated with wound exposure and a high risk of implant failure.

In a study with 8 to 10 years follow-up, de Moraes et al. (2015) confirmed that there are no differences when comparing implant survival in non-grafted and grafted sites with bone from the iliac crest, presenting implant failures below $6 \%$. Although the iliac crest bone is essentially cancellous and the bone in the mandibular ramus is essentially cortical, the current success rates in this study are over $95 \%$. Motamedian et al. (2016), in a systematic review, analyzed the success rates of autologous block grafts vs. block allografts, finding similar rates; however, they indicated that the ranges are too wide and due to the low number of controlled clinical trials, it is not possible to estimate precise rates. In addition, in their work they indicated that the main concern with autogenous blocks is donor site morbidity, whereas in the case of the allograft, the main concern is the integration of the graft into the receptor site.

The findings of this review indicate that the survival rate of implants installed in reconstructed alveolar ridges with autogenous block grafts from the mandibular ramus is close to $98 \%$, similar to what has been observed in other studies (Clementini et al., 2011), 
and $100 \%$ success was also confirmed in 7 studies (Prousaeffs et al.; Happe; Greenberg et al; Singh et al.; Streckbein et al.; Restoy-Lozano et al.; Sakkas et al.). In an analysis of implant installation times, we observed that all the studies installed the implants after a delay, with an average time estimated for healing until implant installation of 4.9 months.

Given the articles in the search periods, a data meta-analysis was not performed, so that this narrative review with a systematic search presents conclusions in terms of a high implant success rate in sites reconstructed with mandibular ramus bone and low morbidity in the donor site; the need for a second surgical site to obtain the graft and the longer time from treatment to implant rehabilitation continue to be disadvantages.

PARRA, M.; HAIDAR, Z. S., VALDIVIA, O. J.; ARANEDA, N. \& OLATE, S. Uso de rama mandibular para reconstrucción alveolar en implantología oral. Int. J. Odontostomat.,11(2):236-242, 2017.

RESUMEN: Los injertos óseos son ampliamente utilizados en el aumento de rebordes alveolares atróficos para permitir la correcta instalación de implantes. Sitios donantes intraorales, tales como tuberosidad de la maxila, sínfisis y rama mandibular han presentado buenas caracteristicas y resultados, sin embargo la rama mandibular presenta ventajas comparativas que estimulan el aumento en su uso. El objetivo de éste trabajo es describir los resultados actuales de la rama mandibular como sitio donante en la obtención de injertos óseos para ser utilizados en aumentos oseos alveolares en implantología oral y determinar la tasa de sobrevida de los implantes instalados en los sitios injertados. Se realizó una búsqueda sistemática de la literatura científica entre Diciembre del 2000 y Marzo de 2017 en las bases de datos MEDLINE, EMBASE, LILACS y SciELO, analizando cada articulo según el método de diagnóstico y planificación, la reabsorción ósea en el sitio receptor, presencia de complicaciones postoperatorias y tasa de sobrevida de los implantes dentales instalados. Se incluyeron 11 trabajos en este estudio con un promedio de 43 pacientes; los tiempos de seguimiento de los sujetos fluctuaron entre los 6 y 120 meses, considerando además una tasa de éxito promedio de $98,7 \%$ en los implantes instalados en sitios reconstruidos con hueso de rama mandibular; se identificó una baja morbilidad en el sitio donante vinculada principalmente a alteraciones neurosensoriales transitorias. Se puede concluir que continúa siendo una desventajas la necesidad del segundo sitio operatorio para la obtención de injerto y el mayor tiempo que alcanza el tratamiento hasta la rehabilitación del implante; aun asi, el sitio donante de rama mandibular presenta baja morbilidad, alta versatilidad en su empleo y resultados predecibles para la instalación de implantes dentales.

PALABRAS CLAVE: rama mandibular, injerto óseo, implantes dentales

\section{REFERENCES}

Chiapasco, M.; Colletti, G.; Coggiola, A.; Di Martino, G.; Anello, T. \& Romeo, E. Clinical outcome of the use of fresh frozen allogenic bone grafts for the reconstruction of severely resolbed alveolar ridges: preliminary results of a prospective study. Int. J. Oral Maxillofac. Implants, 30: 450-60, 2015.

Clementini, M.; Morlupi, A.; Agrestini, C. \& Ottria L. Success rate of dental implants inserted in autologous bone graft regenerated areas: a systematic review. Oral Implantol.(Rome), 4(3-4):3-10, 2011.

Cordaro, L.; Torsello, F.; Miuccio, M. T.; di Torresanto, V. M. \& Eliopoulos D. Mandibular bone harvesting for alveolar reconstruction and implant placement: subjective and objective cross-sectional evaluation of donor and recipient site up to 4 years. Clin. Oral Implants Res., 22(11):1320-26, 2011.

de Moraes, P. H.; Olate, S.; Lauria, A.; Asprino, L.; de Moraes, M. \& de Albergaria-Barbosa, J. R. 8-10 year follow-up survival of dental implants in maxillae with or without autogenous bone graft reconstruction. Int. J. Clin. Exp. Med., 8(10):19282-9, 2015.

de Oliveira, M.; de Moraes, P. H.; Olate, S.; Alonso, M. B.; Watanabe, P. C.; Haiter-Neto, F. \& de Albergaria-Barbosa, J. R. Morphometric study of mandibular ramus related to sagittal ramus split osteotomy and osteosynthesis. J. Craniofac. Surg., 23(5):14847, 2012.

Deluiz, D.; Oliveira, L.; Fletcher, P.; Pires, F. R.; Nunes, M. A. \& Tinoco, E. M. Fresh-Frozen Bone Allografts in Maxillary Alveolar Augmentation: Analysis of Complications, Adverse Outcomes, and Implant Survival. J. Periodontol., 87(11):1261-67, 2016.

Deluiz, D.; Santos Oliveira, L.; Ramôa Pires, F.; Reiner, T.; Armada, L.; Nunes, M. A. \& Muniz Barretto Tinoco E. Incorporation and Remodeling of Bone Block Allografts in the Maxillary Reconstruction: A Randomized Clinical Trial. Clin. Implant. Dent. Relat. Res., 19(1):180-194, 2017.

Diez, G. F.; Fontão, F. N.; Bassi, A. P.; Gama, J. C. \& Claudino, M. Tomographic follow-up of bone regeneration after bone block harvesting from the mandibular ramus. Int. J. Oral Maxillofac. Surg., 43(3):335-40, 2014.

Dolanmaz, D.; Esen, A.; Yıldırım, G. \& I'nan, Ö. The use of autogeneous mandibular bone block grafts for reconstruction of alveolar defects. Ann. Maxillofac., 5(1):71-6, 2015.

Fariña, R.; Alister, J. P.; Uribe, F.; Olate, S. \& Arriagada A. Indications of Free Grafts in Mandibular Reconstruction, after Removing Benign Tumors: Treatment Algorithm. Plast. Reconstr. Surg. Glob. Open, 4(8):e845, 2016. doi: 10.1097/GOX.0000000000000832. Greenberg, J. A.; Wiltz, M. J. \& Kraut, R. A. Augmentation of the 
anterior maxilla with intraoral onlay grafts for implant placement. Implant. Dent., 21(1):21-4, 2012.

Happe, A. Use of a piezoelectric surgical device to harvest bone grafts from the mandibular ramus: report of 40 cases. Int. J. Periodontics Restorative Dent., 27(3):241-9, 2007.

Lee, H. G. \& Kim, Y. D. Volumetric stability of autogenous bone graft with mandibular body bone: cone-beam computed tomography and three-dimensional reconstruction analysis. J. Korean Assoc. Oral Maxillofac. Surg., 41(5):232-9, 2015.

Motamedian, S. R.; Khojaste, M. \& Khojasteh, A. Success rate of implants placed in autogenous bone blocks versus allogenic bone blocks: A systematic literature review. Ann. Maxillofac. Surg., 6(1):78-90, 2016.

Netto, H. D.; Miranda-Chaves, M. D.; Aatrstrup, B.; Guerra, R. \& Olate, S. Bone Formation in Maxillary Sinus Lift Using Autogenous Bone Graft at 2 and 6 Months. Int. J. Morphol., 34(3):1069-75, 2016.

Netto, H. D.; Olate, S.; Klüppel, L.; do Carmo, A. M.; Vásquez, B. \& Albergaria-Barbosa, J. Histometric analyses of cancellous and cortical interface in autogenous bone grafting. Int. J. Clin. Exp. Pathol., 6(8):1532-7, 2013a.

Netto, H. D.; Olate, S.; Rodriguez-Chessa, J.; Kluppel, L. E.; de Moraes, M. \& Mazzonetto, R. Selección de osteosíntesis en la reconstrucción maxilar con injerto óseo de cresta iliaca. Kiru, 10(2):202-7, 2013b.

Nkenke, E. \& Neukam, F. W. Autogenous bone harvesting and grafting in advanced jaw resorption: morbidity, resorption and implant survival. Eur. J. Oral Implantol., 7(2):203-17, 2014.

Nóia C.F.; Ortega-Lopes, R.; Olate, S.; Duque, T. M.; de Moraes, M. \& Mazzonetto R. Prospective clinical assessment of morbidity after chin bone harvest. J. Craniofac. Surg., 22(6):2195-8, 2011 Nov.

Olate, S.; Almeida, A.; Unibazo, A.; Alister, J. P. Uribe, F.; Martínez, F. \& Huentequeo-Molina, C. Osteotomías craneomaxilofaciales con sistemas ultrasónicos. Rev. Chil. Cir., 65(5):454-62, 2013. https://dx.doi.org/10.4067/S0718-40262013000500015.

Peñarrocha-Oltra, D.; Aloy-Prósper, A.; Cervera-Ballester, J.; Peñarrocha-Diago, M.; Canullo, L. \& Peñarrocha-Diago, M. Implant treatment in atrophic posterior mandibles: vertical regeneration with block bone grafts versus implants with $5.5-\mathrm{mm}$ intrabony length. Int. J. Oral Maxillofac. Implants., 29(3):659-66, 2014.

Proussaefs, P.; Lozada, J.; Kleinman, A. \& Rohrer, M. D. The use of ramus autogenous block grafts for vertical alveolar ridge augmentation and implant placement: a pilot study. Int. J. Oral. Maxillofac. Implants., 17(2):238-48, 2002.

Reininger, D.; Cobo-Vázquez, C.; Monteserín-Matesanz, M. \& LópezQuiles, J. Complications in the use of the mandibular body, ramus and symphysis as donor sites in bone graft surgery. A systematic review. Med. Oral Patol. Oral Cir. Bucal, 21(2):241-9, 2016.

Restoy-Lozano, A.; Dominguez-Mompell, J. L.; Infante-Cossio, P.; Lara-Chao, J. \& Lopez-Pizarro V. Calvarial Bone Grafting for Three-Dimensional Reconstruction of Severe Maxillary Defects: A Case Series. Int. J. Oral Maxillofac. Implants, 30(4):880-90, 2015.

Rocha, F.; de Oliveira, G. R.; Olate, S. \& de Alergaria-Barbosa, J. R. Consideraciones clínicas en la obtención de injertos óseos intraorales. Técnica quirúrgica y evaluación de las complicaciones. Av. Periodon. Implantol., 22(2):71-76, 2010.

Sakkas, A.; loannis, K.; Winter, K.; Schramm, A. \& Wilde, F. Clinical results of autologous bone augmentation harvested from the mandibular ramus prior to implant placement. An analysis of 104 cases. GMS Interdiscip. Plast. Reconstr. Surg. DGPW. 2016;5:Doc21.DOI: 10.3205/iprs000100, URN: urn:nbn:de:0183iprs0001007.

Singh, A.; Gupta, A.; Yadav, A. \& Chaturvedi T. P. Reconstruction of localized maxillary ridge defect with autogenous mandibular ramus block bone graft for dental implant placement. J. Dent. Implant., 3:81-4, 2013.

Soehardi, A.; Meijer, G. J.; Strooband, V. F.; de Koning, M. \& Stoelinga, P. J. The potential of the horizontal ramus of the mandible as a donor site for block and particular grafts in preimplant surgery. Int. J. Oral Maxillofac. Surg., 38(11):1173-8, 2009.

Streckbein, P.; Kähling, C.; Wilbrand, J. F.; Malik, C. Y.; Schaaf, H.; Howaldt, H. P. \& Streckbein, R. Horizontal alveolar ridge augmentation using autologous press fit bone cylinders and microlag-screw fixation: technical note and initial experience. J. Craniomaxillofac. Surg., 42(5):387-91, 2014.

Voss, J. O.; Dieke, T.; Doll, C.; Sachse, C.; Nelson, K.; Raguse, J. K. \& Nahles, S. Retrospective long-term analysis of bone level changes after horizontal alveolar crest reconstruction with autologous bone grafts harvested from the posterior region of the mandible. J. Periodontal Implant. Sci., 46(2):72-83, 2016.

\author{
Dirección para Correspondencia: \\ Dr. Sergio Olate \\ Facultad de Odontología \\ Universidad de La Frontera \\ Temuco \\ CHILE
}

E-mail: sergio.olate@ufrontera.cl

Recibido : 04-03-2017

Aceptado: 11-05-2017 